\title{
Novi pristupi didaktici i uloga školskog knjižničara u obrazovnom procesu
}

\author{
New approaches to didactics and the role of school librarian in the \\ educational process
}

\section{Tatjana Aparac-Jelušić ${ }^{1}$}

SAŽETAK: U radu se donosi kritički osvrt na didaktičke pristupe i modele koji se razvijaju u sklopu ideje obrazovanja u 21. stoljeću. Problematiziraju se izazovi novih tehnologija i njihove primjene u nastavnim procesima te ukazuje na društvene promjene koje utječu na potrebu reformi obrazovnih sustava. Posebno mjesto u radu zauzima rasprava o ulozi školskog knjižničara u nastavi, odnosno potreba prepoznavanja njegovih kompetencija za djelovanje u promjenjivom okruženju. Ističe se potreba za suradnjom nastavnika i školskih knjižničara u cilju podizanja kvalitete obrazovnog procesa.

KLJUČNE RIJEČI: didaktički pristup i modeli, obrazovanje u 21. stoljeću, školski knjižničari, suradnja školskih knjižničara i nastavnika

ABSTRACT: The paper presents a critically based overview of didactic approaches and models that have been developing as a part of the education idea in 21st century. The discussion is focused on challenges provoked by information and telecommunication technology and its applications in the educational processes. The light is also shad upon social changes that influence the process of reform in education. A special attention is paid towards the role of the school librarian (or rather teacher-librarian) in the whole education process and the need to reccognise its competencies for activities taken in changeable environment. Furthermore, the need for cooperation between teachers and school librarians is stresses in order to highlight its value for the education.

KEYWORDS: didactic approaches and models, education in 21st century, school librarian, cooperation between school librarians and teachers

\section{Uvod}

Posljednja dva desetljeća svjedočimo sustavnim pomacima u obrazovanju prema podučavanju koje je usmjereno na učenika. U praksi to znači da se veća pažnja usmjerava prema posebnim potrebama učenika, njihovim interesima, navikama i naklonjenosti određenoj vrsti podučavanja, drugim riječima, radi se o pristupu znanom kao personalizirano učenje. To ne znači da će svaki učenik automatski postati aktivniji, ali će mu odabrani pristup i uporaba primjerenih informacijsko-telekomunikacijskih (IKT) alata i programa olakšati pristup znanju kao i komunikaciju s nastavnikom i kolegama. Novi pristupi idu za tim da olakšaju implementaciju odabranih sadržaja te omoguće oblikovanje vlastitog prostora za rad i stjecanje potrebnih teorijskih spoznaja i praktičnih vještina.

\footnotetext{
Članak je nastao na osnovu istoimenog pozvanog izlaganja na konferenciji COBISS 2018, 28. 11. 2018.

Teorijski dio članka oslanja se na poglavlje iz dokumenta Didactic Framework, koji je izrađen u sklopu projekta EINFOSE: Aparac-Jelušić, T., 2018. An overview of didactic approaches in the 21st Century. Str. 4-9. Dostupno na: http://einfose.ffos.hr/documents/EINFOSE IO4 Didactic Framework.pdf [10. 10. 2018].

${ }_{1}^{1}$ Prof. dr. sc. Tatjana Aparac-Jelušić, u miru, Mrkopalj, Hrvatska, aparact@gmail.com.
} 
Milenijska generacija, koja je odrastala s IKT i informacijama dostupnim 24 sata tijekom tjedna, lakše se snalazi u okruženju koje podržava viševrstan i višestruko ciljan rad, pojedinačno ili u grupama. Te je potrebe i načine rada prepoznala obrazovna zajednica, u nekim sredinama brže i odlučnije u odnosu na nužne promjene koje valja provoditi, a u drugima se tek nazire svijest o potrebama prilagodbe uz odgovarajući oslonac na općeprihvaćena pedagoška i didaktička načela. Uz tradicionalnu in situ, razrednu nastavu, sve se više uvode e-nastavni izvori i računalno potpomognuto podučavanje i učenje, rezultat čega su danas gotovo nezaobilazni modeli miješanog učenja (blended learning), modeli 'izokrenutih' učionica (flipped classroom), online poučavanje, poučavanje temeljeno na video izvorima, otvoreni nastavnih materijala (Open educational Resources - OERs), ili online predmeti namijenjeni svakome tko želi učiti o određenom predmetu ili temi (Massive Open Online Courses - MOOC).

Obrazovanje općenito, a obrazovanje i učenje na daljinu, također i online sistemi kao poseban oblik obrazovanja, baštinili su teorije i modele koje je razvila didaktika kao posebna grana pedagogije. Didaktika se zanima za teorije, ideje i načela, pa tako i za instrukcijski dizajn i aplikacije koje se razvijaju od pojave računalnih sustava u obrazovanju, s ciljem da podrži i osnaži uspješnu provedbu obrazovnih procesa. Međutim, didaktika u 21. stoljeću osobito je izazovno područje s obzirom na nastojanja da otkriva i razvija nove modele i metode koje su primjerene i bliske novim generacijama onih koji uče, kao i nastavnicima koji su suočeni s nizom tehničkih novina i problema, ekonomskih i tehnoloških ograničenja. Didaktika bi se trebala spremno suočavati s izazovima svih vrsta današnjeg nesigurnog društveno-političkog, kulturnog i tehničkog okruženja.

Didaktičke metode, teorije i načela razvijale su se kroz stoljeća. Kao što je poznato, prvi dokazi o sustavnom podučavanju potječu iz razdoblja Sumerana, Egipćana i iz tradicije antičke Grčke. Dakako, obrazovanje je tada bilo omogućeno samo onima koji su pripadali vladajućim slojevima i bili pismeni. Tek početkom 17. stoljeća započinje nastava za široke mase, a razvijaju se i prvi obrazovni kurikuli za mlade. Iz tog doba potječu i nastojanja da se utemelji moderna pedagogija. Jan Komenski, J. F. Herbart, G. Kerschensteiner, H. Parkhurst, John Dewey, William H. Kilpatrick, da spomenemo samo najpoznatije reformatore, ponudili su teorijski okvir moderne didaktike i pedagogije.

Razvoj pedagoške misli i didaktičkih pristupa i modela intenzivira se tijekom 20. stoljeća, o čemu govore brojni objavljeni radovi u kojima se predlažu, obrazlažu i vrednuju ponuđeni modeli. Konstruktivistički koncepti i socio-kulturalne teorije učenja postupno pronalaze svoje mjesto unutar 'tradicionalne' didaktike kao konceptualnog okvira koji je tijekom triju stoljeća bio dominantan, nadograđujući ju i nastojeći utvrditi ciljeve podučavanja u modernom društvu te kritički razmotriti tadašnju praksu. Prema mišljenju Qvortrupa et al. (2016, str. 163), Luhmannova interpretacija didaktike kao teorije ili programa koji omogućuje sustavno promišljanje, inspirativna je za raspravu o različitim teorijama i pristupima kojima se nastoji tumačiti kako društvene promjene utječu na obrazovni process.

Budući da je didaktika koristila, i nadalje koristi, teorijske modele iz drugih disciplina, poglavito iz filozofije, psihologije i sociologije, kako bi ponudila i interpretirala teorijske modele vezane uz podučavanje i učenje, neizbježno se susretala s raznim konceptima autora koji nisu uvijek bili u suglasju, pa čak je primjetno i njihovo posvemašnje razilaženje. Opće je prihvaćeno, međutim, da su stariji didaktički pristupi i koncepti bili usmjereni na tumačenje samog procesa učenja i ulogu nastavnika u tom procesu, a da se noviji fokusiraju na mjesto učenika unutar 
procesa podučavanja i učenja. Posebno mjesto pritom zauzimaju pristupi kojima se nastoji pojasniti teorijsko ishodište e-obrazovanja s naglaskom na mogućnostima primjene IKT-a i prihvatljive modele instrukcijskog dizajna (ID).

Korisno je podsjetiti na to da e-obrazovanje, koje se pojavilo u 1950.-im godinama, vuče korijenje iz programiranog učenja i računalno utemeljenih instrukcija. $U$ to vrijeme dostupna didaktična teorijska osnova, međutim, često je zanemarivana te se novim obrazovnim modelima često pristupalo nekritički, vodeći se uglavnom za tehnološkim novitetima, odnosno novim načinima koji su omogućavali da se udovolji rastućim obrazovnim potrebama novih generacija nakon 2. svjetskog rata.

Dominantne teorije o podučavanju i učenju znatno su se mijenjale tijekom 20. stoljeća, od biheviorizma prema Gestalt teoriji i teoriji mišljenja do kognitivne psihologije. U 1970.-im i 1980.-im, pojavila se nova teorija kojom su se nastojale prevladati ograničenosti kognitivnih pristupa - konstruktivistička teorija učenja. Nova je teorija zagovarala snažniju usmjerenost na učenika i novu ulogu nastavnika na kojega valja gledati ne samo kao na pukog prenositelja znanja, već prije kao osobu koja olakšava aktivno i samousmjeravajuće stjecanje znanja (usp. Brown, Collins and Duguid, 1989, str. 32). Brojni pristupi i dalje su utemeljeni na konstruktivizmu. Koncem 20. stoljeća, valja zabilježiti još jedan pristup, inspiriran idejama Vygotskyog i kulturalnim komparativnim studijama (Vieluf et. al., 2012, str. 28-29) - sociokonstruktivističku teoriju. Ta teorija, utemeljena na istraživanju međuodnosa psiholoških procesa onoga koji uči i socijalnih i situacijskih obilježja okruženja u kojemu se odvija sâm obrazovni proces, uvela je u teorijske rasprave koncepte 'self-directed learning', 'co operative learning', 'self-regulated learning', 'guided discovery', 'scaffolding', 'cognitive apprenticeship', 'teacher-mediated dialogue', 'independent group discussion', 'problem based learning', 'project-based learning', 'knowledge building' etc. (usp. Vieluf et al., 2012).

Pojedini modeli, poput Dick i Carey modela, Carrolsova minimalizma, Gagnéovog ID modela, ili pak Algo-heurističkog modela, ipak su se fokusirali na sâm process učenja, a ne na tehnologiju kao krajnji cilj. Događa se, međutim, da o ulozi ID-a u e-učenju često prevladava nerazumijevanje, ponajviše zbog kompleksnosti sustava e-obrazovanja i nedovoljnog poznavanja pedagoških zahtjeva koje je potrebno ugraditi u te sustave (usp. Siemens, 2002).

Ono što nas posebno zanima u ovome radu je kako se u nove teorije o podučavanju i učenju uklapa školski knjižničar, odnosno koji su sve izazovi pred školskim knjižnicama u promijenjenim uvjetima obrazovanja u digitalnom okruženju.

\section{Okruženje u kojemu se danas uči i podučava}

Na početku se valja priupitati u kakvom se to okruženju nalazimo? Teoretičari nas upozoravaju na to da živimo u vrijeme 'tekuće suvremenosti', u promjenjivom društvu izloženom stalnim i brzim promjenama, koje nas je dovelo u fazu određenog interegnuma. Z. Bauman (2000) uzima sintagmu 'tekuća suvremenost' kao vodeću metaforu za sadašnje stanje u razvoju civilizacije suvremenog doba. Fluidno se ne može fiksirati u prostoru niti vezivati uz vrijeme. Budući da je razvidno da tehnologija silovito zamjenjuje manualne poslove, kako je moguće pripremati mlade za život u stalnoj neizvjesnosti? Pojedini autori (Ghislandi i Facci, 2013; Guo i Wouflin, 2016; Cobo, 2013) ističu da je važno osigurati inovativne i kreativne radnike za budućnost, ali se pritom zanemaruje potreba da bi te i takve radnike trebalo osposobiti da 
promišljaju probleme s kojima se suočavaju. Drugim riječima, nastava bi trebala biti informativna, relevatna, dostupna i pristupačna svim zainteresiranima, zanimljiva i poticajna.

Kako bi se podržale promjene u obrazovnom prostoru na svim razinama, Europska Unija ponudila je niz akcijskih programa, na primjer, eEurope 2002, eLearning Programme 20042006, Europe 2020 Strategy. U tim je programima istaknuto mjesto inovativnih pristupa u obrazovanju (usp. Aparac-Jelušić, 2018), a financijska podrška pruža se s ciljem istraživanja novih modela i obrazovnih okvira. Europski pristupi, vezani uz planiranje i odlučivanje te financijsku potporu istraživanjima i suradnji u procesima e-obrazovanja, bilježe se od 1990.-ih naovamo. Nekoliko je akcijskih programa imalo značajan utjecaj na suradnju obrazovnih ustanova s posebnim naglaskom na nastojanjima da se modernizira obrazovni proces uz primjenu IKT-a i IKT podržanih istraživanja u obrazovanju (na primjer, programi Tempus, Phare i Leonardo da Vinci, Socrates, a zatim i program Erasmus i Erasmus plus). Ti su programi bili obuhvaćeni akcijskim politikama poznatim pod nazivom eEurope 2002, eLearning Programme 2004-2006, Europe 2020 Strategy i dostupni su na mrežnom mjestu Europske komisije. Jedna među 'buzz words', koja se u tim programima spominje, nesumnjivo je riječ 'inovacija', a inovativni pristupi u obrazovanju i podučavanju u ciklusima cjeloživotnog učenja, postali su ključni prioriteti nekoliko vodećih inicijativa u sklopu programa Europe 2020 Strategy, a posebno u programima Agenda for New Skills and Jobs, Youth on the Move, Digital Agenda. Svi ti pristupi prepoznaju IKT kao nezaobilaznu podršku prilikom nastojanja da se postignu ciljevi vezani uz inovativno učenje. Također, nije manje važno da je prepoznata potreba za financijskom podrškom pri istraživanju novih modela i didaktičkih okvira te rezultata njihove primjene u praksi.

Međutim, nakon dvadesetak godina tijekom kojih su se, slijedom utvrđenih načela bolonjskog procesa, događale velike promjene na planu reforme obrazovanja u Europi, razvidno je da implementacija tih načela i novih pristupa nije u cijelosti zaživjela.

Postignute kvalitativne promjene vezuju se sve više uz pojmove informacijskog društva, digitalizaciju, internationacionalizaciju, znanost i istraživanja te kapacitete vezane uz inovativne pristupe, a tek donekle i u različitim stupnjevima naglaska, prema utjecaju ekonomije i ekonomske krize koja prevladava od 2007. naovamo. Međutim, o primjeni didaktičkih načela i njihovoj mogućoj prilagodbi novonastalim uvjetima u obrazovnim procesima općenito, nedovoljno se raspravlja i istražuje pa je teško, a vjerojatno i prerano, zaključivati o kvaliteti novih pristupa i njihovom utjecaju na buduće djelovanje onih koji uče i onih koji podučavaju.

U osnovi, postavlja se pitanje što se događa kad temeljne pretpostavke o obrazovanju te pristupima obrazovanju više nije moguće uspješno primjenjivati? \|li, jesu li se te temeljne pretpostavke izmijenile u vremenu rastuće ovisnosti u tehnologiji? Na koji način postići ostvarenje jedne od najvažnijih misija ljudske vrste - pripremiti mlade (a u današnje vrijeme ne samo mlade!) za život i uputiti ih u zanimanja koja još ne postoje?

Sadašnji pristupi obrazovanju pod snažnim su pritiskom da se kroz obrazovni proces razviju vještine poput rješavanja problema, kritičkog mišljenja, uspješnog komuniciranja, suradništva i samo-upravljanja. Međutim, znademo li kako to postići? 


\section{3 „Nova didaktika“}

Didaktika se uobičajeno drži granom pedagogije koju zanimaju općeniti obrasci, uključujući uvjete pod kojima se podučavanje izvodi i posljedice koje proizvodi obrazovni proces. Također, u fokusu joj je utvrđivanje ciljeva, tumačenje dinamike obrazovnog procesa, analiza društvenih oblika i uvjeta pod kojima se taj process odvija, uključujući načine komuniciranja i prijenosa znanja.

Kako su tijekom 20., a još više 21. stoljeća, ubrzane i silovite tehnološke promjene povećale dostupnost informacija i radikalno promijenile način komuniciranja, tradicionalne metode podučavanja poput memoriziranja, ponavljanja te osnovnog razumijevanja, nisu više dostatne. Prema mišljanju Kapitzkeog (2006) školska djeca u 21. stoljeću brzo usvajaju nove informacije i zahtijevaju razvijenije metode podučavanja i komuniciranja. Kako bi se mogao bolje razumjeti obrazovni kontekst 21. stoljeća, Owston (2007), Scardamalia i Bereiter (2006) predlažu da bi bilo korisno prihvatiti činjenicu da je stjecanje pukog deklarativnog znanja ustuknulo pred pristupima koji zagovaraju ne samo stjecanje znanja, već i ovladavanje vještinama primjene stečenog znanja u praksi, na radnome mjestu i u različitim životnim situacijama; kako koristiti informacije u novim situacijama, kako kritički promišljati o nastavnom gradivu, kako vrednovati njegovu prikladnost.

Literatura je bogata izvještajima i osvrtima na uspješne modele podučavanja i učenja koje je moguće preuzimati i nadograđivati (usp. Brown, 2006). Kako je već rečeno, novi pristupi su uglavnom fokusirani na to kako iskoristiti IKT i Internet, s ciljem postizanja maksimalnih rezultata u procesima učenja i podučavanja. Primjeri za to su otvoreno učenje na daljinu (ODL) i dizajn virtualnog radnog okruženja (VLEs), on-line studijski programi i tečajevi, virtualna sveučilišta, i slično (usp. Ravenscroft, 2001, str. 133). Međutim, mogućnosti online učenja dovele su i do pojave novih 'igrača' i novih oblika učenja (na primjer, privatnih ponuditelja obrazovnih programa na Internetu, odnosno MOOC-a i globalnih sveučilišnih usluga) te novih oblika priznavanja stečenih vještina i kompetencija, na primjer, Open badges.

Društvene i tehnološke promjene, a poglavito Internet, bez sumnje su zavladali obrazovanjem u širokom online okruženju, dovevši do obilja informacija, povećanja broja onih koji izvode obrazovne programe i globalnih izazova za učenje i podučavanje. Novo okruženje omogućuje i nastavniku i učeniku da odaberu sadržaje koje preferiraju, da odlučuju o vremenu i mjestu odvijanja obrazovnih programa, potpomognutih mobilnim aplikacijama (usp. Mancabelli, 2012).

Neki autori, poput, Greenlawa (2015), osjećaju potrebu za novom didaktikom, drugi predlažu vlastite pristupe novim izazovima (usp. Mancabelli, 2012). Za očekivati je stoga da će se obrazovna arena na svim razinama - suočena sa svješću o tome da se postojeće teorije i modeli 'raspadaju' - potražiti neku novu didaktiku kao osnovu za prevladavanje neželjenih i često neočekivanih implikacija globalne mreže na osobe i informacije o obrazovanju općenito, a poglavito na kurikulum, podučavanje i procjenjivanje ishoda učenja. Tri su sastavnice koje se uključuju u trenutno razvijajući novi didaktički okvir: a) skupine ljudskih bića u nekom odnosu (na primjer, učenici i nastavnici u učionici ili na nekoj platformi za podučavanje/učenje); b) organizacije ljudske prakse i znanja; i c) nizovi artefakata koji se koriste da bi olakšali komunikaciju između prve i druge sastavnice (usp. Winslow, 2010). 
Novi pristupi, koji se temelje na nastojanjima da se reformira postojeći obrazovni sustav, sugeriraju da istraživački utemeljena pedagogija podučavanja može kvalitetno poduprijeti učenje koje postavlja u središte onoga tko uči, razvijajući pritom istraživačke i druge potrebne vještine (usp. Marshall, Smart i Horton, 2010).

U stručnoj literaturi predstavljen je niz rasprava o vještinama za 21. stoljeće (usp. na primjer, Scardamalia i Bereiter, 2006; Brown, 2006; Walser, 2008; Wagner, 2008; Johnson, 2009; Saavedra Rosefsky i Opfer, 2012). Na osnovi pažljivog proučavanja literature o promjenama u obrazovnim procesima, moguće je zaključivati o tome da su najutjecajniji pristupi oni koji su temeljeni na tzv. vještinama i kompetencijama za 21. stoljeće. Ti su pristupi ujedno i doživjeli najviše interpretacija i kritika. O čemu se tu radi? Najčešće spominjane vještine i kompetencije za 21. stoljeće su: pismenost (u svim mogućim varijanatama koje uključuju računalnu, informacijsku, medijsku i druge pismenosti), vještine računanja, istraživačke vještine, financijske vještine, kulturalne i društvene vještine, vještine kritičkog promišljanja, kreativnost, komunikacijske vještine, sposobnosti suradnje, znatiželja, inicijativa, ustrajnost, prilagodljivost, vještina vođenja. Bez obzira na to o kojem se skupu vještina radi, sve se definicije kompetencija i vještina za 21. stoljeće referiraju na mnogovrsne vidove života u današnjem kompleksnom svijetu. Većina se tih vještina usmjeruje prema razmišljanju, učenju i komuniciranju (usp. Saavedra Rosefsky i Opfer, 2012, str. 8; Griffin i Care, 2015). Kako bi se olakšalo uključivanje tih vještina u novi didaktički okvir Saavedra Rosefsky i Opfer (2012, str. 11) predlažu devet pravila slijedom primjene kojih nastavnici mogu oblikovati svoj pristup podučavanju, kako bi ono bilo relevantno a istodobno se moglo prožimati s drugim predmetima. Ne manje važno pritom je podučiti učenike kako treba učiti, raditi u timu te poticati njihovu kreativnost. Taj pristup vodi nas do transformativne pedagogije koja u žarište postavlja nastojanje da se nastavnike ohrabri, kako bi pružali više od pukog prenošenja znanja.

Transformativna pedagogija ide za tim da se omoguće "fundamentalne i poštovanja vrijedne promjene u navikama učenika i analitičkim vještinama, s ciljem olakšavanja njihova rasta, bez obzira na to nudi li se obrazovni program online ili u tradicionalnim oblicima 'licem u lice' i in situ." (Meyers, 2008, str. 220). U tom kontekstu, vezano uz pripremu nastavnika i korištenje raznih nastavnih izvora - analognih i digitalnih - školska knjižnica od neprocjenjive je važnosti za obrazovni proces. Prema mišljenju Prenskyog (2010), današnji učenici imaju vrlo raznolike interese, vještine i načine na koje razmišljaju, što nažalost nije uvijek prepoznato unutar obrazovnog sustava.

S druge strane, uveliko se raspravlja o mogućim pristupima. Pojedini autori, poput Trillinga i Fadela (2009), predstavljaju tehnofilska polazišta u suvremenom obrazovanju. Drugi pak upozoravaju na to da bi prevladavajuća uloga IKT-a mogla ugroziti ulogu nastavnika i humanističke vrijednosti u obrazovnom procesu (usp., na primjer, Postman, 1993; Greenlaw, 2015). Drugim riječima, Prensky (2010) i njegovi sljedbenici nastoje ukazati na nove, učinkovite načine kojima nastavnici mogu uključiti učenike u eksperimentalno partnerstvo pri učenju, poput uvođenja ozbiljnih igara, e-knjiga, uključivanja u društvene mreže. Nasuprot takvim nastojanjima, Postman sumnja u prihvaćanje IKT-a u nastavi kao nečega što je samo po sebi razumljivo te upozorava na opasnost koju totalitarna tehnokracija može izazvati vezano uz moralni razvoj i oblikovanje kulturnog identiteta.

Na ovome mjestu čini se važnim spomenuti još jednu pojavu koja polako pronalazi odgovarajuće mjesto u 'novoj didaktici' - potrebu kritičnog odnosa prema utjecaju velikih 
korporacija na obrazovanje. Dovoljno je pritom prisjetiti se da, na primjer, Microsoft, Google, i Apple potiču nastavnike na korištenje svojih proizvoda u prodaji kojih te korporacije imaju ekonomski interes. Ako se uzmu u pobliže razmatranje principi kojima se rukovode globalne korporacije - poput interoperabilnosti, informacijske transparentnosti, tehničke podrške, decentraliziranog odlučivanja - kao i njihova primjena u budućim radnim okruženjima za koje će trebati temeljito obučeni profesionalci (usp. Flogie, Barle Lakota i Aberšek, 2018, str. 267268), više je no jasno da je nužna reforma obrazovanja samih nastavnika, s ciljem da jasnije sagledavaju i razumijevaju odnose između spoznaje, motivacije, podučavanja i učenja. K tome, nastavnici trebaju moći prevladati napetosti između pristupa temeljenih tehnološki orijentiranih ciljeva i onih koji polaze od važnosti humanističkih vrijednosti u obrazovnim procesima.

Na osnovi navedenih pristupa i izraženih sumnji, valja graditi novu didaktiku, takav didaktički okvir koji će omogućiti, pa čak i predvidjeti, odgovore na obrazovne potrebe u bliskoj budućnosti. Razvidno je da je u 21. stoljeću, oblikovanje inovativnih praksi podučavanja i učenja poticano vizijom prema kojoj kreativni ciljevi učenika trebaju biti sastavni dio svakodnevne metodologije koja se zasniva na prihvatljivoj didaktici. Međutim, novi didaktički pristupi i okviri nisu dostatno istraženi, a kompleksna obrazovna arena zahtijeva produbljena, svrhovita istraživanja koja će ih potvrditi ili odbaciti. Na tom tragu, Flogie, Barle Lakota i Abveršek (2018) ukazuju na zapostavljanje društvene sastavnice i moguće psihološke učinke koje može izazvati nekontrolirana primjena IKT-a u obrazovnim procesima.

Ta stajališta vraćaju nas transformativnoj pedagogiji koja nastoji kritički ispitati studentske pretpostavke i očekivanja, objasniti jesu li te pretpostavke i očekivanja u suglasju s društvenim promjenama i kako je one koji uče moguće pripremiti za društveno aktivno sudjelovanje. Prema našem mišljenju, transformativna pedagogija pruža vrijednu i primjenjivu osnovu za djelovanje i suradnju nastavnika i školskih knjižničara.

\section{4 Školski knjižničari i nastavnici u promjenjivom društvenom okruženju}

Uloga školskih knjižničara u obrazovnom procesu izazovna je i nimalo jednostavna tema, a zasigurno ju nije moguće obraditi u jednome radu ograničena opsega. Namjera nam je stoga naglasak staviti na zadaće i filozofiju knjižničarske profesije iz motrišta školskog knjižničarstva te uputiti na dominantne teorije o knjižničaru, odnosno njegovim zadaćama, znanjima i vještinama potrebnim da bi se te zadaće uspješno ostvarivale u obrazovnom sustavu, ali ne nauštrb zatomljivanja same prirode profesije i njezinih jezgrenih sadržaja.

Poslanje knjižničara, valja odmah kazati, nije lako odrediti. Pokušavali su to mnogi, čak i veliki mislioci, među kojima Jose Ortega y Gasset (1961) na samome početku svojega čuvenog izlaganja s uvjerenjem konstatira da je ono "enormous and frightening“. Da je u profesionalnome smislu poslanje rezulat pojave društvene potrebe za određenim djelovanjem, opće je prihvaćeno gledište. U slučaju knjižničarstva, ta se potreba pojavila tek onda kad je knjiga prihvaćena kao „društveno potrebna“. Povjesničari i sociolozi knjižničarstva temeljito su se pozabavili razvojem i ulogom knjige u društvu. Nedvojbenim se danas čini stajalište da je knjižničarstvo duboko ukorijenjeno u kulturu i da odražava potrebe društva za komuniciranjem kroz vrijeme i prostor. Budući da je, kako nas podsjeća J. H. Shera (1976), svaka veća promjena društvenog ideala rezultirala određenom mogućnošću u knjižnici, tako i 
u današnje vrijeme knjižnica nastoji pronaći uporište za svoju društvenu zadaću, a osobito za zadaću u obrazovnom procesu, uvažavajući promjene koje se zbivaju.

Razumno koristeći IKT, knjižničari mogu pomoći da se smanje prepreke koje učenici osjećaju učeći, osnaži njihovo aktivno sudjelovanje u procesima učenja, povećaju njihove šanse za uspjeh u učenju, oblikuje snažniji osjećaj za potrebu prilagođavajućih komunikativnih vještina i doživljaja škole kao zajednice te da se osiguraju veće mogućnosti fleksibilnog pristupa učenju. Pritom treba polaziti od novih didaktičkih pristupa koji zagovaraju aktivniju ulogu onih koji uče, integraciju tehnološkog znanja, pristupa koji uvažavaju raznolikost i ističu humanističke vrijednosti obrazovnog procesa. Iz perspektive knjižničarstva naglašen je iskorak od analognog $\mathrm{k}$ digitalnom izvoru, odnosno ističe se da se krećemo od objekata prema digitalnim jedinicama građe koje treba na primjeren način približiti i nastavnicima i učenicima. Organizacija informacija i načela njihova pretraživanja, kao temelji profesije knjižničara, pritom su vrijedno uporište. Nadalje, knjižničarska zajednica posebno je osjetljiva i svjesna potrebe da se usmjeri prema raznolikosti, jer se knjižnice doživljavaju i prihvaćaju kao mjesta unutar kojih komuniciraju različite zajednice.

Brojna su istraživanja pokazala da učenici bolje uče kada su aktivno uključeni u nastavu, nego kada slušaju ex cathedra predavanja, odnosno kada su subjekti kojima se znanje prezentira na jednosmjeran način. Međutim, aktivna uključenost učenika u nastavu često se oslanja isključivo na njihove prezentacije vlastitih istraživačkih zadataka pri rješavanju kojih nemaju dostatne upute i podršku nastavnika, pa se sve više oslanjaju na mrežne izvore kao najjednostavniji izbor. Pritom je među učenicima, opće prihvaćeno mišljenje da se na Internetu mogu pronaći svi odgovori. Tako je sve zamjetnije da se među novim generacijama vještine korištenja informacijske tehnologije stječu brže i bez većih napora, ali i to da njihova informacijska pismenost ostaje na vrlo niskoj razini. Naime, učenici često, uz pomoć tražilica, uspijevaju na Internetu pronaći odgovore na jednostavna pitanja i to pojačava njihov osjećaj kompetentnosti. S druge strane, nepoznavanje ili isključivanje drugih izvora informacija, te zaobilaženje knjižnica kao pouzdanih i vjerodostojnih informacijskih središta, osiromašuje ih, u najmanju ruku, za sposobnost argumentacije vlastita izbora. lako su i sami nastavnici često skloni misliti da je razina informacijske pismenosti učenika izuzetno visoka, njihovo nezadovoljstvo seminarskim radovima učenika u kojima citiraju visok postotak neprovjerenih izvora na Internetu (npr., komercijalne mrežne izvore, sažetke, osobne stranice i sl.), a sve manje knjiga i članaka iz časopisa, i njima govori da nešto nije u redu. Očito je da učenici ne mogu samostalno ovladati analitičkim vještinama višeg stupnja složenosti, koje bi im mogle pomoći da pronađu, pročitaju, analiziraju, evaluiraju i sintetiziraju informacije koje pronalaze na Internetu, ili da se samostalno usmjere prema pouzdanim mrežnim izvorima. Međutim, knjižničari u školskim knjižnicama sve više se susreću s različitim vrstama građe i informacija te potrebom da se osigura pristup toj građi različitim skupinama učenika i nastavnika prilikom korištenja online programa za podučavanje.

Međutim, da bi knjižnica mogla uspješno postati sastavni dio nastavnog procesa i mlade ljude poučiti osnovama informacijske pismenosti, izuzetno je važno uvjeriti nastavnike da knjižničari to mogu i znaju. Da to nije ni jednostavno ni lagano pokazuje primjer knjižničarke iz Riverdale Grade School u Portlandu, USA, koja je morala postati „nametljiva“ da bi knjižnicu integrirala u nastavni proces (usp. Manzo, 1997). Kako bi se odgovorilo na raznolike zahtjeve u školi, knjižnica je ponudila programe kojima je doprla do različitih skupina i koji su uključivali 
sadržaje korisne i potrebne u raznim nastavničkim predmetima. U osnovi, suradnički pristup nastavi ne zaustavlja se samo na programima informacijske i medijske pismenosti, već promišlja na koji način podučiti vještinama samoorganiziranja koje su u osnovi bliske knjižničarima, jer se temelje na teoriji organizacije znanja i informacija. Socijalne vještine koje mogu olakšati snalaženje u budućem radnom i društvenom okruženju - na primjer, etičko ponašanje, izbjegavanje plagiranja - također su bliske knjižničarima, jer su sadržane u temeljnim obrazovnim sadržajima knjižničarstva.

Naposlijetku, spomenimo i moguću suradnju knjižničara i nastavnika te instrukcijskih dizajnera na pripremi i korištenju nastavnog sadržaja kroz otvorene nastavne izvore - OER-e koji su velik izazov i nude razne mogućnosti bilo gdje na svijetu gdje je osiguran pristup internetu za svaku osobu koja želi učiti na osnovi kvalitetnih sadržaja (usp. Upadhyay i Upadhyay, 2015). OER-i dobivaju važnu ulogu u nastojanjima da se smanji digitalni jaz, što u sustavu obrazovanja ima posebno važno mjesto. OER-i nisu samo velik izazov za nastavnike, već knjižničarima otvaraju put prema pozicioniranju unutar škole na osnovi vlastitih komptencija vezanih uz 'novu didaktiku', temeljne postulate knjižničarstva i vještine rukovanja programima i alatima za rad u digitalnom okruženju.

\section{Prema zaključnim razmišljanjima}

Ako se priklonimo prevladavajućem mišljenju prema kojemu je puko znanje bilo najvažniji pokretač društvenih promjena u 19.-om i 20.-om stoljeću, ali da je nedostatan oslonac za obrazovanje u 21.-om stoljeću, nužno je potrebno promišljati i razumijevati promjene i moguća rješenja za budući razvoj društva u cjelini, a obrazovnog procesa osobito.

Procesi 'reformiranja' nastavnika i knjižničara nužni su kako bi ih se osposobilo da se nose s kompleksnijim situacijama i sveobuhvatnim razumijevanjem načina na koji se spoznaja, motivacija, učenje i podučavanje odnose međusobno. Štoviše, nastavnici i knjižničari trebaju biti sposobni prevladati raskorak između tehnološki orijentiranih ciljeva i humanističkih pristupa kojima se mogu obogatiti vještine i kompetencije učenika, te ih voditi tako da se ublažuje 'snaga' tehnološkog pristupa i u suvremene obrazovne procese uvodi snažnija humanistička dimenzija.

Umjesto da se sustavno naglašava IKT i vrijednost informacije kao tržišne robe, novi pristupi trebaju uvažavati i primjereno vrednovati mogućnosti da se učenike vodi prema postizanju mudrosti kroz obrazovanje i fokusirati se na nastavnike i knjižničare kao iskusne eksperte i 'Cicerone' koji vode i oblikuju učenikovo učenje. Prema Greenlawu (2015, str. 897) „podučavanje nije jednostavno pitanje da se učenika usmjeri na pokretanje gumba na računalu ili iPad-u, ili da ga se pusti da rješava lagane probleme ili provede projekt" - ono je više od toga, uključuje društvene i psihološke komponete u društvu koje je sustavno izloženo silovitim promjenama, i u kojemu je obrazovanje nadasve osjetljiv proces, ali i temeljno ishodište za odgovor na potrebe za kompetencijama i vještinama danas i u skoroj budućnosti.

$\mathrm{U}$ takvom je okruženju uloga knjižničara bitno promijenjena, premda percepcija te uloge u javnosti, čak i kod samog nastavnog osoblja, nije do kraja sagledana. Kompetentni knjižničari, pripremljeni za rad u tehnološki razvijenom i stalno mijenjajućem okruženju, ovladavaju i znanjima iz pegadogije i psihologije, što ih stavlja u poziciju ravnopravnih sudionika $u$ nastavnim procesima koje obogaćuju svojim temeljnim poznavanjem organizacije znanja, 
pretraživanja informacija i važnosti provjerene, stručno obrađene i procijenjene informacije u obrazovnom procesu.

\section{Reference}

Aparac-Jelušić, T., 2018. An overview of didactics approaches in 21st Century. U: EINFOSE project: Intellectual outcome 4: Didactic framework. Dostupno na:

http://einfose.ffos.hr/intellectual-outputs/o4 [08. 7. 2018].

Bauman, Z., 2000. Liquid modernity. Cambridge: Polity.

Brown, J. S., 2006. New learning environments for the 21st century: exploring the edge. Change, September/October, str. 18-24.

Brown, J. S., Collins, A. i Duguid, P., 1989. Situated cognition and the culture of learning. Educational Researcher, 18(1), str. 32-42.

Cobo, C., 2013. Skills for innovation: envisioning an education that prepares for the changing world. The Curriculum Journal, 24(1), str. 67-85.

Flogie, A., A. Barle Lakota i B. Aberšek, 2018. The psychosocial and cognitive influence of ICT on competences of STEM students. Journal of Baltic Science Education, 17(2), str. 267-276. Dostupno na: http://www.p21.org/our-work/p21-framework [6. 4. 2018].

Ghislandi, P. i Facci, M., 2013. Schools in the digital age: teachers' training role in the innovative use of the interactive whiteboard. Ricerche di Pedagogia e Didattica, 8(1), str. 118.

Greenlaw, J., 2015. Deconstructing the metanarrative of the 21st Century skills movement. Educational Philosophy and Theory, 47(9), str. 894-903. Dostupno na: http://dx.doi.org/10.1080/00131857.2015.1035156 [6. 4. 2018].

Griffin, P. i Care, E. ur., 2015. Assessment and teaching of 21st century skills. Berlin: Springer.

Guo, J. i Woulfin, S., 2016. Twenty-first century creativity: an investigation of how the partnership for 21st century instructional framework reflects the principles of creativity. Roeper Review, 38(3), str. 153-161.

Johnson, P., 2009. The 21st century skills movement. ASCD Express, 67(1), p. 11. Dostupno na: http://www.ascd.org/publications/educational-leadership/sept09/vol67/num01/The21st-Century-Skills-Movement.aspx [12. 10. 2018].

Kapitzke, C., 2006. Internet chatrooms: e-space for youth of the risk society. U: L. T. W. Hin i R. Subramaniam, ur. Handbook of research on literacy in technology at the K-12 level. London: Idea Group Reference. Str. 158-175.

Mancabelli, R., 2012. The three new pillars of 21st Century learning. District Administration, April, str. 6. Dostupno na: www.DistrictAdministration.com [10. 3. 2018].

Manzo, K. K., 1997. Libraries seeking updated role as learning center. Education Week, 16, str. 30. 
Marshall, J. C., Smart, J. i Horton, R. M., 2010. The design and validation of EQUIP: an instrument to assess inquiry-based instruction. International Journal of Science and Mathematics Education, 8(2), str. 299-321.

Meyers, A. S., 2008. Using transformative pedagogy when teaching online. Journal of College Teaching, 56(4), str. 219-224.

Ortega y Gasset, J., 1961. The mission of the librarian. The Antioch Review, 21, str. 135-137.

Owston, R., 2007. Contextual factors that sustain innovative pedagogical practice using technology: an international study. Journal of Educational Change, 8(1), str. 61-77.

Postman, N., 1993. Technopoly: the Surrender of culture to technology. New York, NY: Random House.

Prensky, M., 2010. Teaching digital natives: partnering for real learning. Thousand Oaks, CA: Corwin.

Qvortrup, A. et al., 2016. On the definition of learning. Odense: University Press of Southern Denmark.

Ravenscroft, A., 2001. Designing e-learning interactions in the 21st Century: revisiting and rethinking the role of theory. European Journal of Education, 36(2), str. 133-156.

Saavedra Rosefsky, A. i Opfer, V. D., 2012. Learning 21st-century skills requires 21st-century teaching. Phi Delta Kappan, 94(2), str. 8-13. Dostupno na:

https://www.researchgate.net/publication/262091816_Learning 21st-

Century Skills Requires 21st-Century Teaching [10. 11. 2018].

Scardamalia, M. i Bereiter, C., 2006. Knowledge building: theory, pedagogy, and technology. $\mathrm{U}$ : K. Sawyer. ur. Cambridge handbook of the learning sciences. New York: Cambridge University Press. Str. 97-118.

Shera, J. H., 1976. Introduction to library science: basic elements of library service. Littleton, Co.: Libraries Unlimited.

Siemens, G., 2002. Instructional design in elearning. Elearnspace, September 30. Dostupno na: http://www.elearnspace.org/Articles/InstructionalDesign.htm [10. 10. 2018].

Trilling, B. i Fadel, C., 2009. 21st Century skills: learning for life in our times. San Francisco, CA: Jossy-Bass.

Upadhyay, N., i Upadhyay, S. R., 2015. The role of academic libraries in Open Educational Resources (OER) initiatives. Library Waves, 1(1), str. 28-32.

Vieluf, S., Kaplan, D., Kliemme, E. i Bayer, S., 2012. Teaching practices and pedagogical innovation: evidence from TALIS. OECD Publishing. Dostupno na:

http://dx.doi.org./10.1787/9789264123540-en [10. 10. 2018].

Wagner, T., 2008. The global achievement gap: why even our best schools don't teach the new survival skills our children need - and what we can do about it. New York, NY: Basic Books. 
Walser, N., 2008. Teaching 21st Century skills. Harvard Education Letter, 24(5), str. 1-3. Dostupno na:

https://www.siprep.org/uploaded/ProfessionalDevelopment/Readings/21stCenturySkills.pdf [11. 07. 2018].

Winslow, C., 2010. Comparing theoretical frameworks in didactics of mathematics: the G-OA-model. U: V. Durand-Guerrier, S. Soury-Lavergne, F. Arzarello, ur. Proceedings of CERME 6, January 28th-February 1st 2009, Lyon France. Str. 1675-1684. Dostupno na:

www.inrp.fr/editions/cerme6 [10. 10. 2018]. 